Article

\title{
Antiproliferative and Antioxidant Activities and Mycosporine-Like Amino Acid Profiles of Wild-Harvested and Cultivated Edible Canadian Marine Red Macroalgae
}

\author{
Yasantha Athukorala, Susan Trang, Carmen Kwok and Yvonne V. Yuan * \\ Received: 22 December 2015; Accepted: 14 January 2016; Published: 21 January 2016 \\ Academic Editor: David D. Kitts \\ School of Nutrition, Ryerson University, 350 Victoria St., Toronto, ON M5B 2K3, Canada; \\ yasantha7@yahoo.com (Y.A.); susan.trang1@gmail.com (S.T.); wckwok@ryerson.ca (C.K.) \\ * Correspondence: yyuan@ryerson.ca; Tel.: +1-416-979-5000 (ext. 6827); Fax: +1-416-979-5204
}

\begin{abstract}
Antiproliferative and antioxidant activities and mycosporine-like amino acid (MAA) profiles of methanol extracts from edible wild-harvested (Chondrus crispus, Mastocarpus stellatus, Palmaria palmata) and cultivated (C. crispus) marine red macroalgae were studied herein. Palythine, asterina-330, shinorine, palythinol, porphyra-334 and usujirene MAAs were identified in the macroalgal extracts by LC/MS/MS. Extract reducing activity rankings were $(p<0.001)$ : wild $P$. palmata $>$ cultivated C. crispus $=$ wild M. stellatus $>$ wild low-UV C. crispus $>$ wild high-UV C. crispus; whereas oxygen radical absorbance capacities were $(p<0.001)$ : wild M. stellatus $>$ wild P. palmata $>$ cultivated C. crispus $>$ wild low-UV C. crispus $>$ wild high-UV C. crispus. Extracts were antiproliferative against HeLa and U-937 cells $(p<0.001)$ from $0.125-4 \mathrm{mg} / \mathrm{mL}, 24 \mathrm{~h}$. Wild P. palmata and cultivated C. crispus extracts increased $(p<0.001)$ HeLa caspase-3/7 activities and the proportion of cells arrested at Sub $\mathrm{G}_{1}$ (apoptotic) compared to wild-harvested C. crispus and M. stellatus extracts. HeLa cells incubated with wild P. palmata and cultivated C. crispus extracts also exhibited morphological changes characteristic of apoptosis (shrinkage, rounding). Thus, extracts rich in low-polarity usujirene and polar palythine and asterina-330 MAAs were antiproliferative as inducers of apoptosis in HeLa cells.
\end{abstract}

Keywords: antioxidant activity; antiproliferative activity; apoptosis; Chondrus crispus; Mastocarpus stellatus; Palmaria palmata; mycosporine-like amino acids (MAAs); caspase 3/7; HeLa cells; U-937 cells

\section{Introduction}

Marine macroalgae, or seaweeds (sometimes referred to as sea vegetables) play an integral role in the traditional diets of Pacific and Asian peoples, for reasons associated with the macro- (e.g., protein, lipid, fiber) and micronutrient (e.g., iodine, iron, potassium, $\beta$-carotene, tocols etc.) contents, flavor and texture enhancing properties (e.g., alginates, fucans, agar, carrageenans etc.) of the various marine macroalgae and constituents, as well as potentially contributing to a reduction in diet-related chronic disease risk (i.e., breast and colorectal cancers) in these populations [1]. Marine macroalgae are also present, but much less ubiquitous, in the traditional diets of Icelandic, Welsh, Irish, North, Central and South American coastal peoples. Amongst these edible macroalgae are many species from the Rhodophyta such as "Nori" or "Kim/Gim" (Pyropia tenera or P. yezoensis) in Japan and Korea, "Hana Tsunomata" ${ }^{\mathrm{TM}}$ " (cultivated Chondrus crispus) for the Japanese market, "Ceylon moss" (Gracilaria edulis) in South-west and -east Asia, "Dulse" or "Dillisk/Dilleasc/Creathnach" (Palmaria palmata) in Ireland, Scotland, Iceland, Norway, Atlantic Canada and U.S.A. While many of these red macroalgae are sunor shade-dried, then toasted/roasted or rehydrated and consumed whole such as Nori, Dulse and 
Hana Tsunomata ${ }^{\mathrm{TM}}$; others are utilized as sources of hydrocolloid ingredients for the food industry, such as the carrageenophytes consisting of many members of the order Gigartinales, including "Irish moss" (Chondrus crispus), "False Irish moss" (Mastocarpus stellatus), Eucheuma sp., Kappaphycus sp. and "Red String seaweed" (Sarcodiotheca gaudichaudii); or even direct aqueous extraction of C. crispus for use in regional cuisines such as the Seaweed Pie in Prince Edward Island, Canada or Irish Moss drinks in Central America and the Caribbean.

The first functional food or nutraceutical applications for edible macroalgae date back to approx. 1534 B.C. Egypt, where they were used for the treatment or prevention of breast cancer [1], which has been more recently substantiated by a case-control study where intake of Gim was inversely related to breast cancer risk [2]. Epidemiological data support the hypothesis of diet-related chronic disease risk reduction in populations known to consume macroalgae regularly in the diet: the age-standardized incidence of breast cancer in North America and Western Europe are approx. 76.7 and 89.9 per 100,000 compared to 25.3 and 31.0 in Eastern and Southeastern Asia [3]. Similarly, the incidence of colorectal cancer in North America (35.3 and 25.7 per 100,000 for males and females) and Western Europe (41.2 and 26.3) are greater than in Eastern (21.5 and 14.8) and Southeastern Asia (15.2 and 12.9). Anticarcinogenic mechanisms contributing to the bioactivities of edible macroalgae include increased hepatic antioxidant enzyme activities [4]; radio- and photo-protective effects of algal extracts against UVB (280-320 nm; [5]), UVA (320-400 nm; [6]) and ionizing sources of radiation [4]; as well as induction of apoptosis and cell cycle arrest [7]. Moreover, anti-oxidant and/or -mutagenic effects of edible macroalgae were reported from in vitro and rodent models of colon and skin carcinogenesis, respectively, including tumour initiation suppression in the latter [8,9]. Porphyra umbilicalis extracts protected fibroblasts and keratinocytes against DNA damage and UVA irradiation as described by Schmid and coworkers $[10,11]$. Thus, there is growing interest in the nutraceutical, pharmacognosic and cosmeceutical applications of extracts from edible marine red macroalgae such as $C$. crispus which is a formulation component contained in an international patent application for anti-aging skin cream uses [12].

Many of the antioxidant and UV-protective bioactivities of edible red macroalgae and extracts above can be attributed to the efficacy of cellular constituents against oxidative stress resulting from exposure to temperature variances, tidal flows and UV-irradiation of these intertidal species [13-16]. For example, macroalgal tissue antioxidants (e.g., ascorbate and carotenoids) are typically reduced during Winter and Spring, and increase in Summer and Fall in concert with increased photosynthetically active radiation (PAR, 400-700 nm) and UVA and UVB-irradiation [14,17,18]. Mycosporine-like amino acids (MAAs), comprised of an aminocyclo-hexenone or -hexenimine core conjugated with the nitrogen moiety of an amino-acid or -alcohol (Figure 1), are most abundant in Rhodophyta (red) compared to Chlorophyta (green) and Pheophyta (brown) macroalgal species [19-22]. MAAs are noted to exhibit $\lambda_{\max }$ between $310-360 \mathrm{~nm}$, thus, an UV-absorbing sunscreen protective role for these compounds in macroalgae, corals and marine animals can be deduced from the overlap with UVA and B wavelengths, as well as evidence that the MAA contents of P. palmata and Devaleraea ramentacea specimens wild-harvested prior to the break-up of Spring ice cover were decreased compared to counterparts harvested during the Summer [17]. Previous work from this laboratory demonstrated that $P$. palmata specimens wild-harvested from areas differing in topography exhibited varied MAA profiles: extracts from both low- and high-UV exposed P. palmata contained palythine, shinorine, asterina-330, palythinol and porphyra-334, but the high-UV specimen alone, also contained usujirene [13]. Interestingly, despite similar oxygen radical absorbance capacity (ORAC) antioxidant activities between the two P. palmata extracts, that from the high-UV specimen was more inhibitory of B16-F1 murine skin melanoma cell proliferation. Previously, butanol extracts of wild-harvested high-UV exposed P. palmata exhibited enhanced reducing activity and inhibition of HeLa cell proliferation vs. a low-UV exposed counterpart [14].

Clearly then, as photosynthetic, intertidal organisms, the composition of macroalgae within the same species may be highly variable when wild-harvested; thus, it is important that mariculture 
researchers and producers are cultivating macroalgae from uniform seed stocks in tanks with filtered seawater, fertilizer or other essential nutrients as well as controlled illumination [12,23,24]. Management techniques such as these ensure not only a reliable, year-round supply of biomass with desired attributes such as the Hana Tsunomata ${ }^{\mathrm{TM}}$ produced by Acadian Seaplants, Nova Scotia, Canada, but also potentially give rise to genetic variants of interest from target species. A large body of knowledge exists of the MAA composition of wild-harvested red marine macroalgae from around the globe [19,21,22,25-27]; however, much less is known about Canadian and North American specimens [13] and in particular, cultivated macroalgae [23]. Thus, the objectives of the present study were to determine the MAA profiles and antioxidant activities of extracts from selected wild-harvested and cultivated Atlantic Canadian edible marine red macroalgae, and to determine the effects of these extracts on the proliferation of two human cancer cell lines, one adherent: cervical adenocarcinoma, HeLa cells, and the other suspended: histiocytic lymphoma, U-937 cells.<smiles>COC1=C(NCC(=O)O)CC(O)(CO)CC1=O</smiles>

Mycosporine-glycine<smiles>COC1=C(NCC(=O)O)CC(O)(CO)C/C1=N/CCO</smiles>

Asterina-330<smiles>COC1=C(NCC(=O)O)CC(O)(CO)C/C1=N/C(C)CO</smiles>

Palythinol<smiles>C/C=C/N=C1CC(O)(CO)CC(NCC(=O)O)=C1OC</smiles>

Palythene<smiles>COC1=C(NCC(=O)O)CC(O)(CO)CC1=N</smiles>

Palythine<smiles>COC1=C(NCC(=O)O)CC(O)(CO)C/C1=N\C(CO)C(=O)O</smiles>

Shinorine<smiles>COC1=C(NCC(=O)O)CC(O)(CO)C/C1=N\C(C(=O)O)C(C)O</smiles>

Porphyra-334<smiles>C/C=C\N=C1CC(O)(CO)CC(NCC(=O)O)=C1OC</smiles>

Usujirene

Figure 1. The main mycosporine-like amino acids (MAAs) identified in Rhodophyta. 


\section{Results}

\subsection{Red Macroalgal Extract Mycosporine-Like Amino Acid Profiles}

Multiple reaction monitoring (MRM) positive ion fragmentation pattern LC/MS/MS data confirmed the presence of six MAAs in the wild-harvested and cultivated red macroalgal methanol extracts (in order of elution): palythine, asterina-330, shinorine, palythinol, porphyra-334 and usujirene (Table 1). Palythine was present in substantial quantities in all five red macroalgal extracts with greatest peak area counts in cultivated C. crispus and moderate counts in wild-harvested high-UV C. crispus, P. palmata and low-UV C. crispus, and less in the wild-harvested M. stellatus extract. While asterina-330, with greatest peak area counts in cultivated C. crispus and wild-harvested high-UV C. crispus, and shinorine with greatest peak area counts in wild-harvested M. stellatus and cultivated C. crispus, were also present in all five extracts, albeit at lower peak area counts (Table 1). Palythinol was present in sizeable quantities in the wild-harvested $P$. palmata extract, with much less in wild-harvested M. stellatus and trace amounts in the wild-harvested high-UV C. crispus extract, but none detected in the others, based on the decreased confidence of identification when peak area counts range between 2000-3000 [28]. Similarly, porphyra-334 was present in sizeable quantities in only the wild-harvested P. palmata extract, with much lower peak area counts in the wild-harvested M. stellatus, high-UV and cultivated C. crispus extracts and trace amounts in the wild-harvested low-UV C. crispus extract. Usujirene was present in substantial quantities in only the wild-harvested P. palmata and M. stellatus extracts, with none detected in the other extracts (Table 1).

Table 1. Mycosporine-like amino acid composition of wild-harvested and cultivated red macroalgal extracts determined from LC/MS/MS multiple reaction monitoring ${ }^{1}$.

\begin{tabular}{|c|c|c|c|c|c|c|}
\hline & Palythine & Asterina-330 & Shinorine & Palythinol & Porphyra-334 & Usujirene \\
\hline Red Macroalgae & & & Peak Area Counts $\left(\times 10^{3}\right)$ & & & \\
\hline $\begin{array}{c}\text { Wild } \\
\text { P. palmata }\end{array}$ & 5040 & 2040 & 658 & 3120 & 5220 & 13,000 \\
\hline $\begin{array}{l}\text { Wild low-UV } \\
\text { C. crispus }\end{array}$ & 5010 & 2720 & 268 & $\mathrm{ND}^{1}$ & 8.8 & $\mathrm{ND}^{1}$ \\
\hline $\begin{array}{l}\text { Wild high-UV } \\
\text { C. crispus }\end{array}$ & 6930 & 4110 & 233 & 7.8 & 24.9 & $\mathrm{ND}^{1}$ \\
\hline $\begin{array}{c}\text { Cult. } \\
\text { C. crispus }\end{array}$ & 19,000 & 6160 & 2440 & 3.1 & 23.4 & $\mathrm{ND}^{1}$ \\
\hline Wild M. stellatus & 3470 & 1880 & 6600 & 98.6 & 315 & 1610 \\
\hline
\end{tabular}

The wild-harvested P. palmata extract contained the greatest MRM total peak area counts $\left(29,078 \times 10^{3}\right)$ for MAAs, followed by cultivated C. crispus $\left(27,627 \times 10^{3}\right)$, wild-harvested M. stellatus $\left(13,974 \times 10^{3}\right)$, high-UV C. crispus $\left(11,306 \times 10^{3}\right)$ and low-UV C. crispus $\left(8007 \times 10^{3} ;\right.$ Table 1$)$ extracts. The wild-harvested P. palmata extract alone contained substantial peak area counts of all six confirmed MAAs with usujirene predominating (Table 1); while that of wild-harvested M. stellatus contained substantial peak area counts for all six MAAs with shinorine predominating, followed by palythine, asterina-330, usujirene and smaller amounts of porphyra-334 and palythinol. The cultivated and wild-harvested high-UV and low-UV C. crispus extracts contained substantial peak area counts of three MAAs with palythine predominating (particularly in the cultivated specimen), followed by asterina-330, shinorine and small amounts of porphyra-334 (Table 1). It is noteworthy that the wild-harvested high-UV C. crispus extract contained a greater total peak area count for MAAs compared to the low-UV specimen, including greater peak area counts for palythine, asterina-330 and porphyra-334. 


\subsection{Red Macroalgal Extract Antioxidant Activities}

The reducing activities of the wild-harvested and cultivated red macroalgal extracts varied in the following order $(p<0.001)$ : wild-harvested P. palmata $>$ cultivated C. crispus $=$ wild-harvested M. stellatus $>$ wild-harvested low-UV C. crispus $>$ high-UV C. crispus (Table 2). On the other hand, ORAC values of the wild-harvested and cultivated red macroalgal extracts varied as follows $(p<0.001)$ : wild-harvested M. stellatus $>$ P. palmata $>$ cultivated C. crispus $>$ wild-harvested low-UV C. crispus $>$ high-UV C. crispus (Table 2).

Table 2. Reducing activity and oxygen radical absorbance capacity (ORAC) of extracts from wild-harvested and cultivated red macroalgae.

\begin{tabular}{|c|c|c|}
\hline Red Macroalgae & $\begin{array}{c}\text { Reducing Activity } \\
\text { (mg Ascorbic Acid Equivalents/g Extract) }\end{array}$ & $\begin{array}{c}\text { ORAC } \\
\text { ( } \mu \text { moles Trolox Equivalents/g Extract) }\end{array}$ \\
\hline Wild P.palmata & $3.61 \pm 0.171^{\mathrm{a}}$ & $45.13 \pm 0.674^{b}$ \\
\hline Wild low-UV C. crispus & $1.02 \pm 0.003^{c}$ & $21.58 \pm 0.46^{\mathrm{d}}$ \\
\hline Wild high-UV C. crispus & $0.789 \pm 0.088^{\mathrm{d}}$ & $14.15 \pm 0.31^{\mathrm{e}}$ \\
\hline Cult. C. crispus & $2.06 \pm 0.030^{b}$ & $33.02 \pm 1.12^{c}$ \\
\hline Wild M. stellatus & $1.58 \pm 0.154^{b}$ & $57.83 \pm 0.722^{\mathrm{a}}$ \\
\hline
\end{tabular}

\subsection{Red Macroalgal Extract Antiproliferative Effects on HeLa and U-937 Cell Lines}

The wild-harvested and cultivated red macroalgal extracts inhibited HeLa cell proliferation in a dose-dependent manner $(p<0.001)$ after $24 \mathrm{~h}$ incubation (Figure $2 \mathrm{~A})$. There were also significant differences $(p<0.001)$ in the inhibition of HeLa cell proliferation between the wild-harvested and cultivated red macroalgal extracts at all concentrations tested. Overall, the strongest antiproliferative effects $(p<0.001)$ were observed with the extracts from the wild-harvested $M$. stellatus = low-UV C. crispus $>$ high-UV C. crispus $>$ P. palmata extract $>$ cultivated C. crispus extract. There was an interaction $(p<0.001)$ between dose and red macroalgal extract in that the cultivated C. crispus extract exhibited the least efficacy at the low dose concentrations $(0.125-1.0 \mathrm{mg} / \mathrm{mL})$, but high efficacy at the highest dose concentrations $(2.0-4.0 \mathrm{mg} / \mathrm{mL}$ ) compared to the other red macroalgal extracts (Figure 2A). Conversely, the wild-harvested low-UV C. crispus extract exhibited high efficacy at the lower concentrations $(0.125-1.0 \mathrm{mg} / \mathrm{mL})$, but was less efficacious at the highest concentrations $(2.0-4.0 \mathrm{mg} / \mathrm{mL})$ compared to the other red macroalgal extracts.

Similar to the HeLa cells above, the wild-harvested and cultivated red macroalgal extracts inhibited U-937 cell proliferation in a dose-dependent manner $(p<0.001)$ after 24 h incubation (Figure 2B). Inhibition of U-937 cell proliferation was significantly different $(p<0.001)$ between the wild-harvested and cultivated red macroalgal extracts at $0.25-1.0 \mathrm{mg} / \mathrm{mL}$ concentrations only (Figure 2B). The red macroalgal extract antiproliferative effects $(p<0.001)$ were greatest with the wild-harvested high-UV C. crispus $\geqslant$ low-UV C. crispus $\geqslant$ M. stellatus $\geqslant$ cultivated C. crispus $>$ wild-harvested P. palmata extracts. While the wild-harvested P. palmata extract was the least efficacious compared to the wild-harvested high-UV and low-UV C. crispus extracts at the low dose concentrations $(0.125-1.0 \mathrm{mg} / \mathrm{mL})$ against U-937 cell proliferation, there were no differences between red macroalgal extract efficacies at the higher dose concentrations $(2.0-4.0 \mathrm{mg} / \mathrm{mL}$; Figure 2B). Due to the fewer red macroalgal extract treatment differences observed with U-937 cells above, the remaining cellular analyses to further evaluate the potential mechanisms underlying the antiproliferative effects were performed with HeLa cells only. 

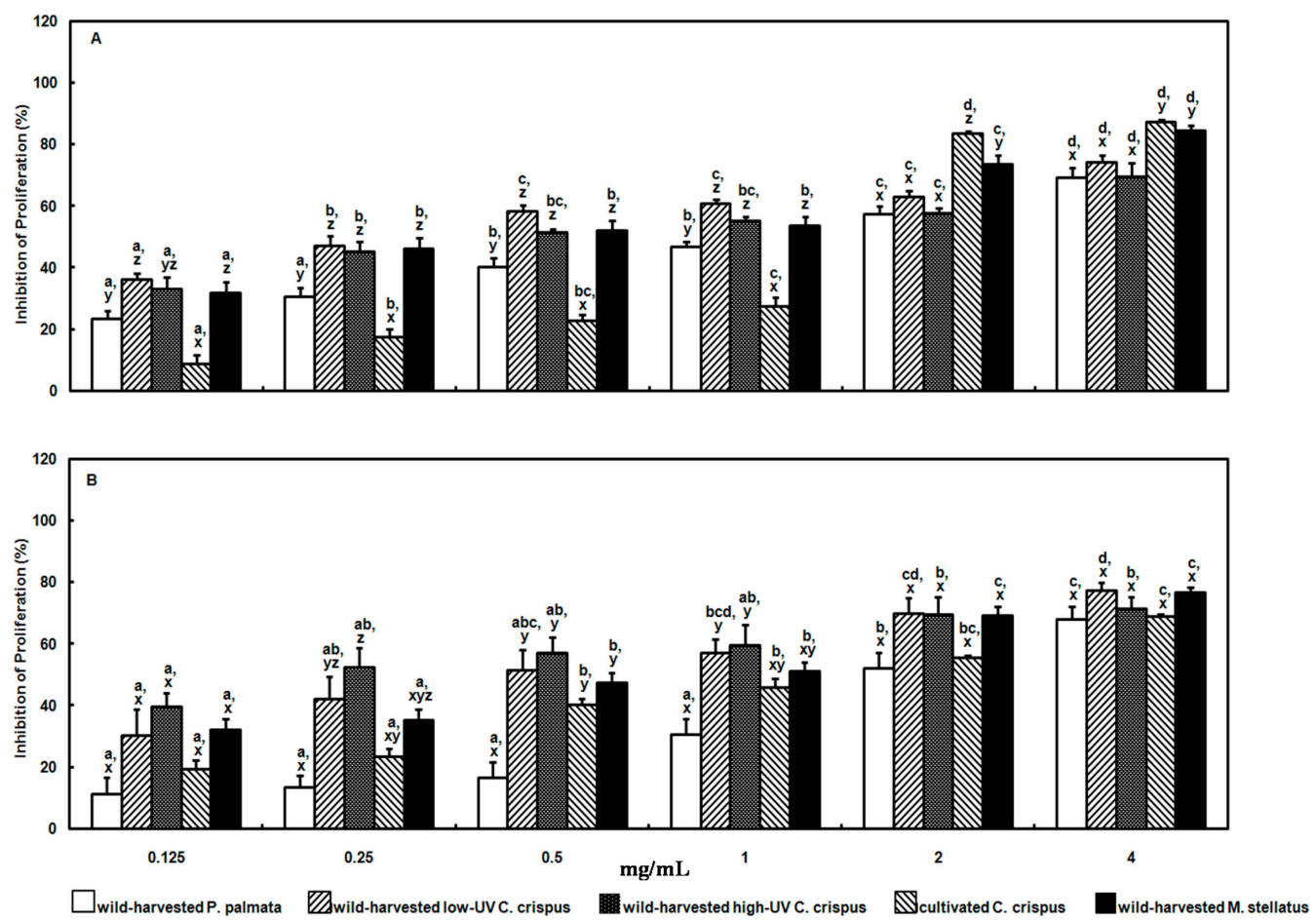

Figure 2. Effect of wild-harvested and cultivated red macroalgal extracts on the proliferation of human cervical adenocarcinoma HeLa (Panel A) and histiocytic lymphoma U-937 (Panel B) cells over 24 h. a-d indicate a significant difference $(p<0.001)$ between concentrations of each red macroalgal extract; $\mathrm{x}-\mathrm{z}$ indicate a significant difference $(p<0.001)$ between the red macroalgal extracts at each concentration.

\subsection{Red Macroalgal Extract Effects on HeLa Cell Morphology}

Incubation with the cultivated C. crispus (Figure 3A) and wild-harvested P. palmata (Figure 3B) extracts induced marked changes in HeLa cell morphology with increasing concentrations of the extracts. HeLa cell morphology was altered from the typical rhomboid-tetrahedral shape observed with the untreated control cells into progressively more contracted and rounded cells characteristic of apoptosis with lower cell density and ultimately, membrane blebbing and apoptotic bodies at the 1.0 and $4.0 \mathrm{mg} / \mathrm{mL}$ concentrations.
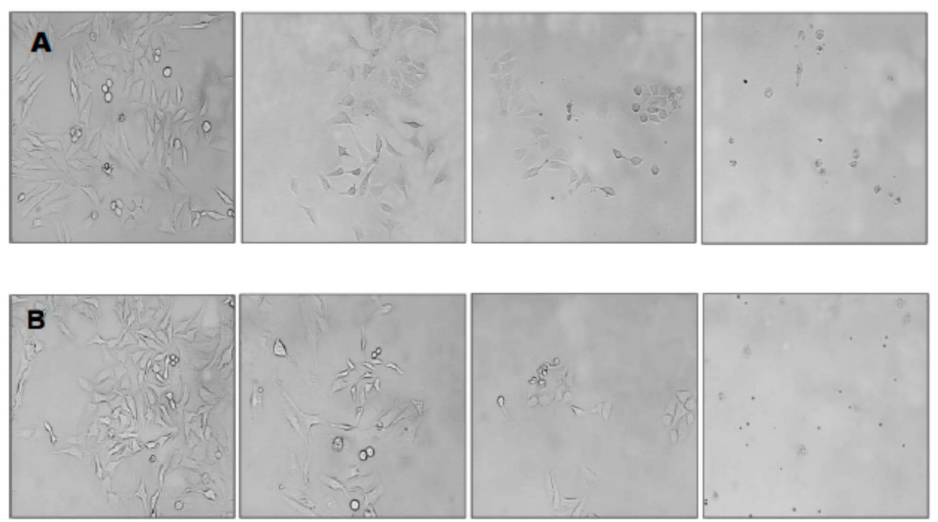

Control $\quad 0.25 \mathrm{mg} / \mathrm{mL} \quad 1 \mathrm{mg} / \mathrm{mL} \quad 4 \mathrm{mg} / \mathrm{mL}$

Figure 3. Morphological changes observed in HeLa cells treated with cultivated C. crispus (Panel A) and wild-harvested P. palmata extracts (Panel B) using an inverted microscope $(200 \times)$. 


\subsection{Red Macroalgal Extract Effects on HeLa Cell Caspase 3/7 Activities}

HeLa cell caspase $3 / 7$ activity was influenced by the wild-harvested and cultivated red macroalgal extracts in a dose-dependent manner $(p<0.001)$ after $24 \mathrm{~h}$ incubation (Table 3$)$. The greatest induction of caspase $3 / 7$ activity in HeLa cells was observed with $2.00 \mathrm{mg} / \mathrm{mL}$ of the wild-harvested P. palmata and the cultivated $C$. crispus extracts compared to untreated control cells, all red macroalgal extracts at the lower dose of $0.25 \mathrm{mg} / \mathrm{mL}$ and the wild-harvested M. stellatus and both high-UV and lo-UV C. crispus extracts at $2.00 \mathrm{mg} / \mathrm{mL}$. Thus, only the wild-harvested P. palmata and cultivated C. crispus extracts were studied for the cell cycle analyses below.

Table 3. Effect of wild-harvested and cultivated red macroalgal extracts on HeLa cell Caspase $3 / 7$ activity ${ }^{1}$.

\begin{tabular}{ccc}
\hline \multirow{2}{*}{ Red Macroalgae } & \multicolumn{2}{c}{ Extract Concentration } \\
\cline { 2 - 3 } & $\mathbf{0 . 2 5} \mathbf{~} \mathbf{g} / \mathbf{m L}$ & $\mathbf{2 . 0 0} \mathbf{~ m g / m L}$ \\
\hline Wild P. palmata & $0.98 \pm 0.14^{\mathrm{a}}$ & $3.36 \pm 0.52^{\mathrm{c}}$ \\
Wild low-UV C. crispus & $0.62 \pm 0.10^{\mathrm{a}}$ & $0.91 \pm 0.16^{\mathrm{a}}$ \\
Wild high-UV C. crispus & $0.12 \pm 0.04^{\mathrm{a}}$ & $0.92 \pm 0.06^{\mathrm{a}}$ \\
Cult. C. crispus & $0.16 \pm 0.04^{\mathrm{a}}$ & $2.44 \pm 0.05^{\mathrm{b}}$ \\
Wild M. stellatus & $0.62 \pm 0.32^{\mathrm{a}}$ & $0.68 \pm 0.12^{\mathrm{a}}$ \\
Control & $1.00 \pm 0.00^{\mathrm{a}}$ & \\
\hline
\end{tabular}

${ }^{1}$ Caspase (aspartate-specific cysteine proteases) 3/7 activity is expressed as folds over control after $60 \mathrm{~min}$ incubation; ${ }^{\mathrm{a}-\mathrm{c}}$ indicate significant differences $(p<0.05)$ between doses and red macroalgal extracts.

\subsection{Red Macroalgal Extract Effects on HeLa Cell Cycle}

The proportions of HeLa cells in the cell cycle phases were also influenced by the wild-harvested P. palmata and cultivated C. crispus extracts in a dose-dependent manner $(p<0.001)$ after $24 \mathrm{~h}$ incubation (Table 4; Figure 4). While the cultivated C. crispus extract increased the proportion of HeLa cells in Sub $\mathrm{G}_{1}$ from 0.25 to $4.00 \mathrm{mg} / \mathrm{mL}$ concentrations and in comparison to untreated control cells, there was only a trend towards an increased proportion of HeLa cells in Sub $G_{1}$ with exposure to the wild-harvested P. palmata extract $(p=0.155)$. The wild-harvested P. palmata and cultivated C. crispus extracts did not influence $(p>0.05)$ the proportions of HeLa cells in the mitosis $(M)$, Gap $1\left(G_{1}\right)$, synthesis (S) or Gap 2 $\left(G_{2}\right)$ phases (Figure 4).

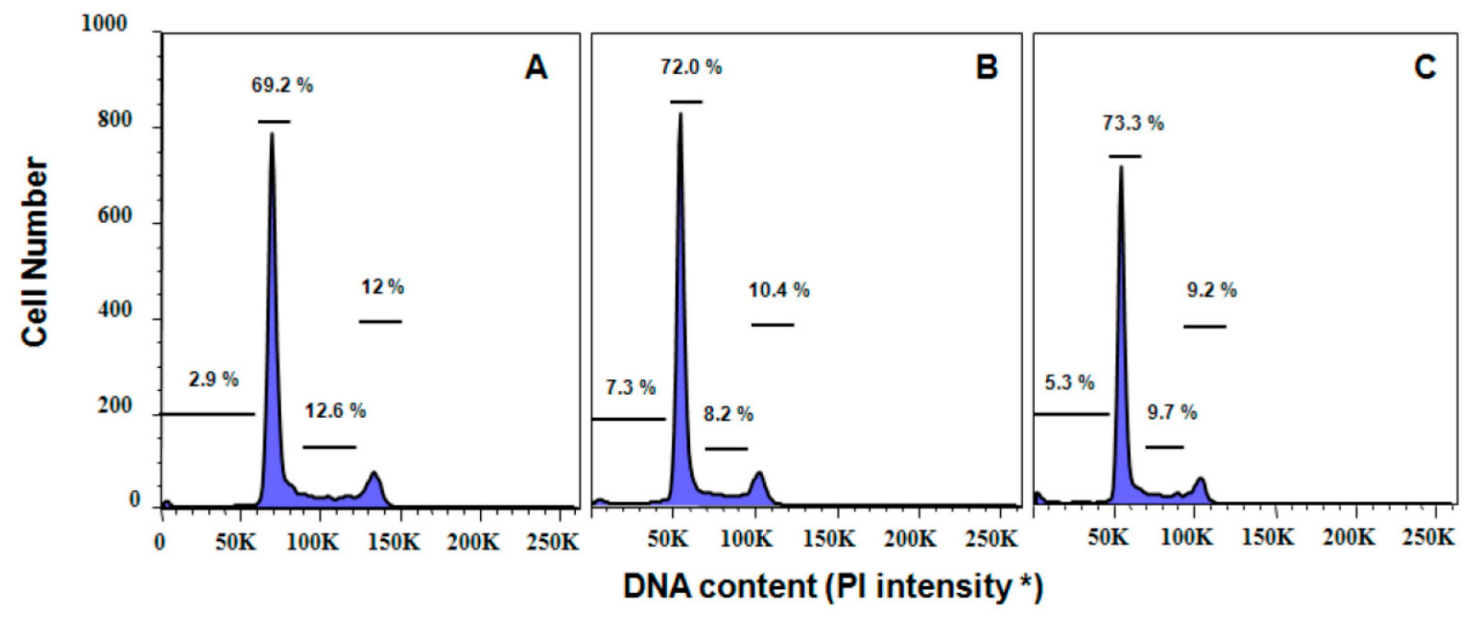

Figure 4. Cell cycle DNA histograms of HeLa cells treated with PBS (Panel A); $4 \mathrm{mg} / \mathrm{mL}$ cultivated C. crispus extract (Panel B); and $4 \mathrm{mg} / \mathrm{mL}$ wild-harvested P. palmata extract (Panel C) at $24 \mathrm{~h}$. Values represent (from left to right) the percentages of cells in $G_{0}, G_{1}, S$ and $G_{2} M$ phases. * PI intensity, Propidium iodide in arbitrary units of fluorescence intensity. 
Table 4. Effect of wild-harvested and cultivated red macroalgal extracts on HeLa cell cycle ${ }^{1}$.

\begin{tabular}{ccc}
\hline Red Macroalgae & Concentration $(\mathbf{m g} / \mathbf{m L})$ & Sub G $_{\mathbf{1}}(\%)$ \\
\hline & 0.25 & $2.89 \pm 0.38^{\mathrm{a}}$ \\
Wild P. palmata & 2.00 & $3.43 \pm 0.38^{\mathrm{a}}$ \\
& 4.00 & $4.13 \pm 0.64^{\mathrm{a}}$ \\
\hline & 0.25 & $3.04 \pm 0.33^{\mathrm{a}}$ \\
Cult. C. crispus & 2.00 & $5.74 \pm 1.24^{\mathrm{a}, \mathrm{b}}$ \\
& 4.00 & $7.50 \pm 1.45^{\mathrm{b}}$ \\
\hline Control & 0.00 & $2.69 \pm 0.23^{\mathrm{a}}$
\end{tabular}

${ }^{1} 10,000$ events were collected from each sample for the analyses; cell cycle phases were analyzed using FlowJo software. ${ }^{a, b}$ indicate significant differences $(p<0.05)$ between doses and red macroalgal extracts.

\section{Discussion}

This study is the first to report the MAA profiles of aqueous methanolic extracts from a cultivated C. crispus specimen as well as wild-harvested C. crispus specimens from low- and high-UV exposed locations, wild-harvested M. stellatus which co-occurs with C. crispus in the intertidal zone and P. palmata, all edible red marine macroalgae from temperate zone locations in western Nova Scotia, and Wood and Grand Manan Islands, New Brunswick, Canada, respectively. We extend these findings by reporting the antioxidant capacity, comprising reducing activities and ORAC values of these extracts; as well as the HeLa (cervical) and U-937 (lymphocyte) human adenocarcinoma and histiocytic lymphoma cell antiproliferative activities of these red macroalgal extracts. Moreover, we describe the apoptotic effects of the cultivated C. crispus and wild-harvested P. palmata extacts on HeLa cells herein. We have previously reported that aqueous methanolic extracts of wild-harvested P. palmata specimens from low-UV and high-UV exposed locations on Grand Manan Island $\left(44^{\circ} 40.0^{\prime} \mathrm{N}, 66^{\circ} 45.0^{\prime} \mathrm{W}\right)$ exhibited different MAA profiles, with the low-UV sample containing five of the six MAAs herein, except for the low polarity usujirene, and the high-UV P. palmata extract containing all six MAAs; however the ORAC values for the extracts were not different [13]. It is noteworthy that the high-UV P. palmata extract was more antiproliferative against B16-F1 murine skin melanoma cells over 24-48 h compared to the low-UV extract. Using HPLC-DAD chromatography, we determined that the wild-harvested low- and high-UV P. palmata extracts both contained a majority of porphyra-334 and palythine, with smaller amounts of palythinol, shinorine and asterina-330. However, the amount of usujirene in the high-UV P. palmata extract was likely underestimated due to the greater $\lambda_{\max }(356 \mathrm{~nm})$ and molar extinction coefficient associated with the conjugated double-bond structure of this MAA (Figure 1; [13]). Thus, it is noteworthy that in the present study, LC/MS/MS multiple reaction monitoring indicated that usujirene was the predominant MAA in the wild-harvested P. palmata specimen from the same high-UV location, with lower amounts of porphyra-334 and palythine, palythinol, asterina-330 and shinorine. These results with wild-harvested P. palmata specimens from a temperature zone climate, are different from those of P. palmata harvested from Arctic waters (Spitsbergen, Norway; $78^{\circ} 55.5^{\prime} \mathrm{N}, 11^{\circ} 56.0^{\prime} \mathrm{E}$ ) containing a majority of porphyra-334, with smaller amounts of a compound with $\lambda_{\max }$ of $357 \mathrm{~nm}$ (possibly usujirene) and palythine, palythene (trans isomer of usujirene; Figure 1), mycosporine-glycine and palythinol [21]. Compared to other MAAs, usujirene is noted to absorb strongly in the UVA wavelength range which predominates at lower latitudes, in combination with stronger solar radiation, a shorter light path and thinner ozone layer $[13,20]$. Furthermore, it is noteworthy that porphyra-334 may undergo conversion to usujirene via the shikimic acid pathway [29].

To the best of our knowledge, the present study is the first to elucidate the MAA profile of a cultivated specimen of $C$. crispus. The carrageenophytes $C$. crispus and M. stellatus are not only similar in morphology, but also co-occur at the shoreline with C. crispus inhabiting the low intertidal zone and M. stellatus higher up on shore and in a mixed zone. Interestingly, these two species of red macroalgae (from two different families within the order Gigartinales) vary considerably in 
MAA synthesis and thereby, profiles: C. crispus is noted for a high rate of synthesis of shinorine under UV-irradiation, and this MAA is amongst the first to be synthesized by this species [20,30]. Exposing C. crispus to PAR + UV-irradiation results in the additional synthesis of palythine: when C. crispus (containing traces of palythine; collected from the North Sea, $54^{\circ} 11^{\prime} \mathrm{N}, 7^{\circ} 53^{\prime} \mathrm{E}$ ) was exposed to unfiltered light as well as light with UVA and UVB filters, shinorine was rapidly synthesized followed by a decline in this MAA, and induction of palythine and asterina-330 [31]. When C. crispus (containing palythine, asterina-330 and palythene) was exposed to UVB irradiation, shinorine was synthesized de novo and levels of asterina-330 and palythene increased two-fold, while the amount of palythine remained unchanged [30]. Thus, the predominance of palythine, followed by asterina-330 and lesser amounts of shinorine in the wild-harvested low- and high-UV C. crispus extracts (from western Nova Scotia $\left(43^{\circ} 82^{\prime} \mathrm{N}, 66^{\circ} 15^{\prime} \mathrm{W}\right)$ herein, are in agreement with an inverse relationship (i.e., reciprocal changes reflecting a precursor-product relationship) between shinorine and palythine, as well as asterina-330 concentrations in this red macroalga [20]. The greater MAA total peak area counts for the wild-harvested high-UV C. crispus extract compared to the low-UV specimen are indicative of the increased oxidative stress, solar and UV-irradiation exposure associated with the shallow water habitat of the former, compared to the deeper water location of the latter. Moreover, the increased amounts of the most abundant MAAs palythine $\left(\lambda_{\max } 320 \mathrm{~nm}\right)$, asterina-330 $\left(\lambda_{\max } 330 \mathrm{~nm}\right)$ as well as minor amounts of porphyra-334 $\left(\lambda_{\max } 332 \mathrm{~nm}\right)$ and palythinol $\left(\lambda_{\max } 330 \mathrm{~nm}\right)$ but similar amounts of shinorine ( $\left.\lambda_{\max } 332\right)$ in the wild-harvested high-UV C. crispus extract reflect the greater exposure to UVA-irradiation in the temperate zone shallow water depths of western Nova Scotia and thereby bioconversion of shinorine to form palythine and asterina-330 as above. It is noteworthy that the cultivated C. crispus extract contained $2.44 \times$ the MAA total peak area counts compared to the wild-harvested high-UV specimen, reflecting a greatly increased synthesis of shinorine and bioconversion of this MAA to yield palythine and asterina-330. The cultivated C. crispus was very highly pigmented, appearing uniformly dark purple compared to the variegated red purple with some green, and pale green of the wild-harvested low-UV and high-UV C. crispus, respectively. These pigmentation differences reflect the tissue levels of the key light-harvesting pigment in red macroalgae, $(R)$-phycoerythrin, which is known to vary inversely with UV-irradiation exposure [14]. Thus, the cultivation techniques used have uniquely maximized MAA synthesis of the selected C. crispus seedstock in tanks with micro-filtered seawater and nutrients [32]. Interestingly, M. stellatus extracts are often comprised solely of shinorine $[21,25,30,33]$. For example, $M$. stellatus (wild-harvested from the North Sea, as above) subjected to UVB-irradiation over 5 days, exhibited a $1.67 \times$ increase in shinorine content without any trace of other MAAs [30]. The extract from wild-harvested M. stellatus from Wood Island, New Brunswick $\left(44^{\circ} 37^{\prime} \mathrm{N}, 66^{\circ} 50^{\prime} \mathrm{W}\right)$ in the present study, contained not only a majority of shinorine, but also considerable amounts of palythine, asterina-330, usujirene and porphyra-334. Thus, it is likely that the lower latitude of growth of the M. stellatus herein, compared to the North Sea, exposed the specimen to increased total solar and UVA-irradiation as discussed above, resulting in bioconversion of accumulated shinorine to form palythine and asterina-330, as well as conversion of porphyra-334 into usujirene since the latter absorbs more strongly in the UVA range than the former MAA [20].

In the present study, the aqueous methanol extracts of the edible wild-harvested and cultivated red macroalgae exhibited variable antioxidant efficacies when expressed as single electron transfer reducing activity and hydrogen atom transfer ORAC values. Overall, the red macroalgal extracts exhibited weak reducing activities with $1 \mathrm{~g}$ of extract equivalent to milligrams of L-ascorbic acid. This is not unexpected, as sun-drying and storage of macroalgae such as P. palmata are noted to markedly reduce the antioxidant molecule content, including L-ascorbate, $\alpha$ - and $\beta$-carotene [14]. Alternatively, ORAC values represent the ability of chain-breaking antioxidants to quench free radicals through hydrogen atom transfer to the carbon or peroxyl radicals from AAPH decomposition and reaction with molecular oxygen. Differences in the antioxidant activities between the wild-harvested red macroalgal extracts are indicative of the endogenous cellular antioxidant capacity required to protect against 
environmental oxidative stresses associated with differences in intertidal zone habitat and UV-exposure. Previously, aqueous methanolic and 1-butanol soluble extracts from wild-harvested high- and low-UV P. palmata specimens exhibited similar ORAC and AAPH-radical quenching activities, despite differing MAA profiles and greater reducing activity in the high-UV P. palmata 1-butanol extract compared to a low-UV counterpart $[13,14]$. That the extract from the wild-harvested P. palmata specimen (collected from the low-lying exposed eastern shore of Grand Manan Island with high UV-irradiation) exhibited the greatest reducing and second highest ORAC activities herein may be attributable to the total MAA content, but also to the predominance of usujirene in the MAA profile of this red macroalga. Nakayama and coworkers [23] proposed that the strong antioxidant efficacy of usujirene may be attributable to hydrogen ion abstraction from the cycloheximine ring at C-4, C-6 or the methylene group at C-9 of the glycine residue with resonance stabilization from the conjugated double-bonds of the cis-unsaturated chain at C-11 on the double-bonded nitrogen in series with the carbon ring double-bond structure. The wild-harvested P. palmata extract herein was also characterized by the greatest amount of porphyra-334; this MAA demonstrated moderate inhibition of AAPH-induced lipid peroxidation when present in a 9.6:1 ratio mixture of porphyra-334:shinorine [34].

The differences in intertidal zone habitats occupied by M. stellatus compared to C. crispus have been identified as conferring greater stress tolerance and a competitive advantage of the former over the latter, as evidenced by a greater total MAA content as well as endogenous antioxidant capacity comprising L-ascorbate, $\alpha$-tocopherol, $\beta$-carotene and antioxidant enzymes; [16,30]. Likewise, herein we report greater MAA total peak area counts for the wild-harvested $M$. stellatus extract vs. the high-UV and low-UV C. crispus extracts, respectively, in addition to greater reducing and ORAC activities in the former compared to latter species. The stronger antioxidant efficacies of the wild-harvested $M$. stellatus extract likely reflect the hydrogen ion abstraction mechanisms of the main constituent MAA, shinorine associated with the cycloheximine ring at C-4, C-6 or the methylene group at C-9 of the glycine residue with some resonance stabilization from the carbon ring double-bond structure, in addition to the efficacy of the usujirene content, as above [23]. Moreover, Dunlap and coworkers [35] reported the dose-dependent inhibition of AAPH-induced phosphatidylcholine peroxidation by shinorine. It is also plausible that palythine, which when present in a 27.9:9:4.3:1 ratio of mycosporine-glycine:palythine:palythinol:asterina-330, potentially contributed to the strong inhibition of AAPH-induced peroxidation of these MAAs [34], played a role in the antioxidant effects of the wild-harvested M. stellatus extract herein. On the other hand, the weaker antioxidant activities of both the wild-harvested high-UV and low-UV C. crispus extracts are indicative of the efficacy of the main constituent MAA, palythine, as above, in addition to asterina-330 which exhibited little inhibition of AAPH-induced peroxidation when present in a 8:1 ratio of asterina-330:palythine [34]. The antioxidant activities of the cultivated C. crispus extract likely resulted from the efficacy of the predominant MAA, palythine as a hydrogen atom donor as well as that of shinorine, with resonance stabilization from the carbon ring double-bond structure in the latter MAA, as above. These lines of evidence from two different antioxidant mechanisms, suggest that the reducing and ORAC antioxidant activities of the wild-harvested P. palmata, M. stellatus, high- and low-UV C. crispus and cultivated C. crispus red macroalgal extracts can be attributed largely to the hydrogen atom transfer efficacies of usujirene, shinorine and palythine, with a minor contribution from asterina-330.

The aqueous methanolic extracts of the wild-harvested and cultivated red macroalgae herein exhibited dose- and species-dependent antiproliferative effects against human adenocarcinoma cervical (HeLa) and histiocytic lymphoma (U-937) cells in vitro. The EC 50 values calculated for the wild-harvested P. palmata, low-UV C. crispus, high-UV C. crispus, cultivated C. crispus and wild-harvested $M$. stellatus extract inhibition of HeLa cell proliferation after $24 \mathrm{~h}$ incubation were: 1.83, 0.457, 1.06, 1.73 and $0.747 \mathrm{mg} / \mathrm{mL}$; whereas those for U-937 cells were: $2.51,0.772,0.344,1.99$ and $1.15 \mathrm{mg} / \mathrm{mL}$. Previously, we reported that aqueous methanolic extracts from a high-UV exposed P. palmata specimen exhibited greater antiproliferative effects against B16-F1 murine melanoma cells over $48 \mathrm{~h}$ than a low-UV exposed counterpart [13]. It was hypothesized that these effects 
may be attributable to the passive uptake of the low-polarity, weakly acidic MAA, usujirene across cell membranes. Similarly, Moo-Puc and co-workers [36] proposed that membrane permeation by low-polarity/lipophilic compounds was responsible for the cytotoxic and antiproliferative effects of Yucatán Rhodophyta extracts such as Gracilaria cervicornis which exhibited an $\mathrm{EC}_{50}$ value of $0.076 \mathrm{mg} / \mathrm{mL}$ against HeLa cells. Other workers have reported a dose-dependent and apparently saturable, active transport of the highly polar, strongly acidic MAA, shinorine across cell membranes to be antiproliferative against human skin carcinoma A431 cells [33]. The above $\mathrm{EC}_{50}$ values represent low antiproliferative efficacies in comparison to the U.S. National Cancer Institute standard of an $\mathrm{EC}_{50} \leqslant 30 \mu \mathrm{g} / \mathrm{mL}$ extract on cancer cells, which is not surprising, given the mixture of MAAs and varying concentrations present in our extracts. More recently, a case-control study revealed that the average intake and frequency of Gim consumption was inversely associated with breast cancer risk in pre- as well as post-menopausal women [2]. It is noteworthy that several animal models of carcinogen-induced intestinal adenocarcinoma, as well as implanted sarcoma-180 ascites cell studies have attributed the anticarcinogenic efficacies of dietary red macroalgae in part to the sulfated polysaccharides, but also free radical scavenging and antioxidant small molecules [2,37,38].

In the present study, the proliferation of both HeLa and U-937 cells were considerably inhibited by the wild-harvested $M$. stellatus extract containing the polar, strong acid shinorine, albeit the efficacy of this extract was not as strong in the latter cell line. Active transport of shinorine may also have been a factor in the slightly weaker antiproliferative effects of the cultivated C. crispus extract on HeLa and U-937 cells, given the reduced peak area counts for shinorine compared to that in the wild-harvested M. stellatus extract. Membrane permeation by the low-polarity, weakly acidic usujirene may also have played a role in the antiproliferative effects of the wild-harvested $M$. stellatus extract above. Similarly, usujirene may have been efficacious in the antiproliferative effects of the wild-harvested P. palmata extract against HeLa and U-037 cells. On the other hand, the antiproliferative efficacies of the wild-harvested high-UV and low-UV C. crispus extracts against HeLa and U-937 cells are unclear at present, but may potentially be associated with the trans-membrane movement of other polar, weakly acidic MAAs, namely palythine and asterina-330.

In other work, the proliferation of HT-29 colon cancer cells was strongly inhibited by $0.020 \mathrm{mg} / \mathrm{mL}$ of a methanolic extract from the Rhodophyta Symphyocladia latiuscula, associated with an increased proportion of apoptotic cells [7]. Induction of apoptosis (i.e., programmed cell death) in the HT-29 cells was associated with activation of the caspase-3/7 cascade (aspartate-specific cysteine proteases) and poly (ADP-ribose) polymerase (PARP) activation. Apoptosis, also known as type I cell death in mammalian cells, is noted to be characterized by distinct alterations in the nucleus (comprising chromatin condensation and fragmentation), cell shrinkage and blebbing of the plasma membrane and ultimately, formation of apoptotic structures containing nuclear or cytosolic components [39]. The mechanisms underlying apoptosis involve proteolytic activity of a family of caspases which participate in the initiation, execution and regulation of apoptosis, leading to breakdown of the cytoskeleton, disruption of cellular metabolism and fragmentation of nuclear material [39]. Thus, the caspase family is noted to comprise upstream initiators (caspase-8, -9 and -10) which activate the downstream effectors of apoptosis (caspase-3, -6 and -7). Activation of caspases can occur by differing signaling routes: the extrinsic death receptor pathway which plays a role in tissue homeostasis and the immune system, or the intrinsic mitochondrial pathway which responds to a variety of extra- or intracellular insults such as DNA damage; it is this latter pathway which predominates in programmed cell death. Thus, it is noteworthy that both the wild-harvested P. palmata and cultivated C. crispus extracts increased caspase-3/7 activity in HeLa cells. Caspase-3/7 activation has been reported to be responsible for cleaving cell cycle regulators, including PARP, which induce cell cycle arrest, leading to induction of apoptosis as above [7].

The induction of apoptosis in HeLa cells in the present study was confirmed by the dose-response changes in cell morphology as a result of incubation with the cultivated C. crispus and wild-harvested P. palmata extracts. Moreover, cell cycle analyses also confirmed that apoptosis played a role in the 
antiproliferative effects of the cultivated C. crispus and wild-harvested P. palmata extracts on HeLa cells with pronounced dose-dependent $\mathrm{Sub} \mathrm{G}_{1}$ phase (apoptotic) arrests after $24 \mathrm{~h}$. Interestingly, while the induction of caspase-3/-7 activity in HeLa cells was stronger with the wild-harvested P. palmata extract compared to that from cultivated C. crispus and the untreated control cells, the accumulation of Sub $G_{1}$ apoptotic cells was greater in HeLa cells exposed to the latter, compared to the former extract. These differences may relate to the timing and duration of the respective phenomena, as apoptosis is noted to occur very rapidly, typically within hours [39]; thus, caspase-3/-7 activation would be expected to precede mitochondrial and DNA fragmentation effects leading to cell cycle arrest. The lack of dose-dependent effects of the wild-harvested M. stellatus, low-UV and high-UV C. crispus extracts on HeLa cell caspase-3/-7 activity compared to those discussed above, does not eliminate the possibility that initiator caspase (caspase-8, -9 or -10 ) activities or other cell cycle regulators may have been affected. It is noteworthy that HeLa caspase-3/-7 activities were increased by the two red macroalgal extracts with the greatest MAA total peak area counts in the cultivated $C$. crispus and the wild-harvested P. palmata extracts.

In conclusion, the MAA profiles of aqueous methanol extracts from the edible wild-harvested and cultivated marine red macroalgae studied herein exhibited differences attributable to not only species-specific differences in MAA synthesis and bioconversion, but also UV-exposure in a temperate climate zone. Red macroalgal extract reducing and ORAC activities reflected the differing efficacies of component MAAs as electron and/or hydrogen atom donors and free radical quenchers; as well as the relative amounts of MAAs in individual extracts, with the greatest efficacies observed with the wild-harvested P. palmata, rich in usujirene, porphyra-334 and palythine, and wild-harvested M. stellatus extracts, rich in shinorine. The HeLa and U-937 cell antiproliferative effects of the wild-harvested P. palmata, M. stellatus and cultivated C. crispus extracts likely reflected passive uptake and active transport of usujirene and shinorine, respectively, across cell membranes as discussed above. The antiproliferative effects of the wild-harvested low-UV and high-UV C. crispus extracts remain unclear, but may have been due to transport of other polar MAAs across cell membranes. HeLa cell death via apoptosis was confirmed as the mechanism underlying the effects of the wild-harvested P. palmata and cultivated C. crispus extracts from not only increased effector caspase-3/-7 activities, but also cell-cycle arrest at $S u b G_{1}$ in treated cells; cell morphologies also indicated characteristic apoptotic changes. Further work with purified MAAs will help to further elucidate the protective antioxidant and antiproliferative mechanisms of these unique UV-absorbing marine red macroalgal constituents. Moreover, animal model studies will determine the potential protective bioactivities of dietary wild-harvested and cultivated red macroalgae studied herein, and their constituents, against diet-related chronic diseases. This work will be instrumental in furthering the development of mariculture producers and processors of edible marine red macroalgae in the processed and functional food industries.

\section{Experimental Section}

\subsection{Materials and Reagents}

Three specimens of Chondrus crispus (Class Florideophyceae, Subclass Rhodymeniophycidae, Order Gigartinales, Family Gigartinaceae) were kindly provided by Alan Critchley (Acadian Seaplants Limited, Dartmouth, NS, Canada): the first, wild-harvested from western Nova Scotia in deeper waters (low-UV); the second, wild-harvested from western Nova Scotia in shallow waters (high-UV); the third, a cultivated specimen; as well as a Mastocarpus stellatus (Order Gigartinales, Family Phyllophoraceae) specimen wild-harvested from Wood Island, New Brunswick. Certified organic (Organic Crop Improvement Association International, Lincoln, NE, USA) P. palmata (dulse; Class Florideophyceae, Subclass Nemaliaphycidae ,Order Palmariales, Family Palmariaceae) was obtained from Atlantic Mariculture Ltd. (Grand Manan, NB, Canada). The dulse was wild-harvested from the low-lying eastern shores of Grand Manan Island with increased exposure to UV radiation as 
previously described by Yuan et al. [13,14]. HeLa and U-937 cells were purchased from American Type Culture Collection (ATCC, Manassas, VA, USA). Solvents (formic acid, methanol, acetonitrile $(\mathrm{ACN})$ ) were purchased from Fisher Scientific (Mississauga, ON, Canada) and were all of HPLC grade. L-ascorbic acid, trichloroacetic acid (TCA), 6-hydroxy-2,5,7,8-tetramethylchroman-2-carboxylic acid (Trolox), fluorescein Na-salt and 2,2'-azo-bis(2-amidinopropane) dihydrochloride (AAPH), 3-(4,5dimethylthiazolyl-2)-2,5-diphenyltetrazolium bromide (MTT) were purchased from Sigma-Aldrich Canada (Oakville, ON, Canada). Dulbecco's phosphate buffered saline (D-PBS), Dulbecco's modified Eagle's medium (DMEM), D-glucose, L-glutamine, sodium pyruvate, heat-inactivated foetal bovine serum (FBS), penicillin/streptomycin and TrypLE Express were purchased from Invitrogen Life Technologies (Burlington, ON, Canada). Water $\left(\mathrm{H}_{2} \mathrm{O}\right)$ used as a solvent or in mobile phases was purified using a Millipore Super-Q Water System (Millipore, Bedford, MA, USA). Sample absorbances were read using a Lamba 20 UV/Vis Spectrometer (Perkin-Elmer, Norwalk, CT, USA).

\subsection{Preparation of Macroalgal Extracts}

Lyophilized, sun-dried and comminuted red macroalgal samples were ground to 40 mesh screen size prior to soaking in $\mathrm{H}_{2} \mathrm{O}, 4^{\circ} \mathrm{C}$, overnight, followed by methanol extraction and centrifugation $\left(4{ }^{\circ} \mathrm{C}, 15 \mathrm{~min}, 3000 \mathrm{rpm}\right)$ for collection of supernatants as previously described by Yuan and coworkers [13]. Sample material was extracted twice more with methanol and the supernatants pooled and concentrated prior to solubilization in $\mathrm{H}_{2} \mathrm{O}$ and sonication. Extracts were filtered $(0.20 \mu)$ into a glass vial with an insert (Chromatographic Specialties Inc., Brockville, ON, Canada) for LC/MS/MS analyses, antioxidant and cell proliferation assays.

\section{3. $L C / M S / M S$}

HPLC-mass spectral analyses were carried out at the Mass Spectrometry Facility for Small Molecules at The Hospital for Sick Children (Toronto, ON, Canada). Mobile phases were $0.2 \%$ formic acid in $\mathrm{H}_{2} \mathrm{O}$ and $0.2 \%$ formic acid in $\mathrm{ACN}$, respectively. Chromatography was performed with an Agilent 1100 Series LC (Agilent Technologies, Mississauga, ON, Canada) equipped with an Inertsil ODS-3 column ( $5 \mu, 4.6 \times 250 \mathrm{~mm}$; GL Sciences, Inc. USA, Torrance, CA, USA) using a gradient elution starting with $0.2 \%$ formic acid in $\mathrm{H}_{2} \mathrm{O}$ and ending with $0.2 \%$ formic acid in $\mathrm{ACN}$ over $20 \mathrm{~min}$, at a flow rate of $1.0 \mathrm{~mL} / \mathrm{min}, 30^{\circ} \mathrm{C}$.

Triple quadrupole LC/MS/MS (API 4000; Applied Biosystems/MDS Sciex Instruments, Toronto, ON, Canada) in positive ion mode with a turbo spray ionization source was used to determine molecular masses of separated MAAs using Analyst NT version 1.4.1 Software. The instrument was operated in the multiple reaction monitoring (MRM) mode to acquire total product ion counts. The transitions monitored ranged between $\mathrm{m} / \mathrm{z} 347.2$ and $186.2 \mathrm{~m} / \mathrm{z}$ using nitrogen as the collision gas at 150.9 bar. The declustering potential was $-50.00 \mathrm{~V}$, collision energy was $-42.00 \mathrm{~V}$, dwell time was $30.0 \mathrm{~ms}$, ion spray voltage (Sciex Turbo Ion Spray TIS Probe) was set to $-4200 \mathrm{~V}$ and the source temperature was $650.0^{\circ} \mathrm{C}$. MAAs were identified using published data for formula weights, $[\mathrm{M}+\mathrm{H}]^{+}$ values and fragmentation patterns $[13,25,40]$ in the absence of commercially available MAA standards.

\subsection{Reducing Activity}

The reducing activities of the red macroalgal extracts were determined as previously described by Yuan and coworkers [14]. Sample absorbances were read at $700 \mathrm{~nm}$, and reducing activities expressed as ascorbic acid equivalents from the L-ascorbic acid calibration curve. Each macroalgal extract was assayed in quadruplicate.

\subsection{Oxygen Radical Absorbance Capacity (ORAC-fluorescein) Assay}

The ORAC values of the red macroalgal extracts were determined as described by Yuan and coworkers [13] with modifications. Briefly, aliquots of red macroalgal extracts or the Trolox reference antioxidant were mixed with $60 \mathrm{nM}$ fluorescein in a black 96-well cliniplate (Thermo Scientific, VWR 
Canlab, Mississauga, ON, Canada) in the presence of $75 \mathrm{mM}$ phosphate buffer, $\mathrm{pH} 7.0$ and incubated at $37^{\circ} \mathrm{C}, 10 \mathrm{~min}$. AAPH was then added for a final concentration of $12 \mathrm{mM}$ in each well and the plate shaken for $10 \mathrm{~s}$ prior to the initiation of fluorescence readings, with excitation and emission wavelengths of 485 and $538 \mathrm{~nm}$, respectively (Fluorskan Ascent, Thermo Scientific) at $37^{\circ} \mathrm{C}$. Fluorescence readings were taken every $60 \mathrm{~s}$ for $80 \mathrm{~min}$; the microplate was shaken for $10 \mathrm{~s}$ prior to each reading. Raw data were exported from the Ascent Software 2.6 to a spreadsheet for calculation of the areas under the fluorescence decay curves. Red macroalgal extract ORAC values were expressed as $\mu$ moles Trolox equivalents/g extract.

\subsection{Cell Proliferation}

HeLa cells were maintained in DMEM with $4.5 \mathrm{~g} / \mathrm{L}$ D-glucose, L-glutamine, and $110 \mathrm{mg} / \mathrm{L}$ sodium pyruvate and supplemented with $10 \%(v / v)$ heat-inactivated FBS and $1 \%(v / v)$ penicillin/ streptomycin in a humidified environment with $5 \% \mathrm{CO}_{2}, 37^{\circ} \mathrm{C}$. U-937 cells were maintained in DMEM supplemented with $10 \%(v / v)$ FBS and $1 \%(v / v)$ penicillin/streptomycin in an environment as above. HeLa cells were grown up to $60 \%-80 \%$ confluence in $75 \mathrm{~cm}^{2}$ tissue culture treated culture flasks and were passaged using D-PBS and TrypLE Express (trypsin containing 1mM of EDTA in D-PBS); whereas U-937 cells were passaged using PBS and TrypLE Express.

\subsection{MTT Assay}

HeLa and U-937 cells were harvested and seeded (180-190 $\mu \mathrm{L})$ into flat bottom 96-well plates at a density of $2 \times 10^{4}$ cells $/ \mathrm{mL}$ for the respective experiments. HeLa cells were allowed to attach for $16 \mathrm{~h}$ and then treated with either D-PBS (control) or red macroalgal extracts (10-20 $\mu \mathrm{L}$ ) at final concentrations of $0.125-4 \mathrm{mg} / \mathrm{mL}$ of media [14]; whereas U-937 cells (suspended cells) were treated $15 \mathrm{~h}$ after transfer to 96-well plate, as above. After $24 \mathrm{~h}$ incubation, $50 \mu \mathrm{L}$ MTT solubilized in D-PBS $(2 \mathrm{mg} / \mathrm{mL})$ was added to each well, with further incubation for $4 \mathrm{~h}$. U-937 cells were centrifuged in plates, $500 \times g, 21^{\circ} \mathrm{C}$. The reagents from each well were carefully removed by vacuum and $150 \mu \mathrm{L}$ dimethyl sulfoxide was added. The 96-well plates were mixed on a nutating mixer (VWR Canlab) at $25 \mathrm{rpm}, 20 \mathrm{~min}$ at room temperature to dissolve the formazan crystals, and the absorbances at $570 \mathrm{~nm}$ read with a Multiskan Ascent Microplate Reader (Thermo Labsystems, Franklin, MA, USA). The inhibition of HeLa or U-937 cell proliferation by red algal extracts was calculated as follows:

$$
\% \text { Inhibition }=(\text { Abs570nm control }- \text { Abs570nm sample }) \div \text { Abs570nm control } \times 100
$$

A subset of HeLa cells incubated with the cultivated C. crispus and wild-harvested P. palmata extracts were viewed and photographed using an inverted microscope at $200 \times$ magnification.

\subsection{Propidium Iodide (PI) Staining for Flow Cytometry}

HeLa cells were seeded in a 6-well plate (Cellstar, Greiner Bio-One, Monroe, NC, USA) at a density of $2 \times 10^{5}$ cells $/ \mathrm{mL}$ and allowed to attach overnight at $37{ }^{\circ} \mathrm{C}, 5 \% \mathrm{CO}_{2}$ with a fully humidified atmosphere. Cells were treated with either PBS (control) or red macroalgal extracts $(0.25,2$ and $4 \mathrm{mg} / \mathrm{mL}$ ) and incubated for $24 \mathrm{~h}$. Then, floating and trypsinized HeLa cells were collected, centrifuged at $400 \times g, 4^{\circ} \mathrm{C}, 5 \mathrm{~min}$. Supernatants were aspirated and the cell pellets washed with $1 \mathrm{~mL}$ cold PBS, prior to fixing cells with $1 \mathrm{~mL} 80 \%$ ethanol and storage overnight, $4{ }^{\circ} \mathrm{C}$. Ethanol-fixed HeLa cells were washed twice with $1 \mathrm{~mL}$ cold PBS, followed by suspension in $500 \mu \mathrm{L}$ RNAse $(2 \mathrm{mg} / \mathrm{mL}$; Ribonuclease A from bovine pancreas, Sigma-Aldrich) in PBS for $5 \mathrm{~min}$ at room temperature, and stained with PI (0.1 mg/mL; Calbiochem Corp., La Jolla, CA, USA) in PBS containing 0.6\% (w/v) of NP-40 (Bioshop Canada Inc., Burlington, ON, Canada) for $30 \mathrm{~min}$ in the dark. Cells were strained using filter cap tubes to remove clumps (polystyrene round-bottom tube with cell-strainer cap; BD Falcon ${ }^{\mathrm{TM}}$, Franklin Lakes, NJ, USA), wrapped in aluminum foil, placed on ice and analysed immediately using a Becton Dickinson LSRII SC Flow Cytometer at 488 nm excitation (detector D, 600 LP and 610/20 BP; BD Biosciences, 
San Jose, CA, USA) running BD FACSDiva 6.1.2 software (Becton Dickinson BioSciences, San Jose, CA, USA). 10,000 events were collected from each sample for analyses. Cell cycle phases and profiles were analysed using FlowJo software (Tree Star, Inc. Ashland, OR, USA).

\subsection{Caspase-3/7 Activity Assay}

Caspase-3/7 activity was determined using an Apo-One ${ }^{\circledR}$ Homogeneous Caspase-3/7 Assay kit (Promega Corporation, Madison, WI, USA) according to the manufacturer's directions. Briefly, HeLa cells were seeded in a black 96-well plate (Cellstar, Greiner Bio-One) at a density of $2 \times 10^{4}$ cells $/ \mathrm{mL}$ and allowed to attach overnight. Cells were then treated with either PBS (control) or red macroalgal extracts $(0.25$ and $2 \mathrm{mg} / \mathrm{mL})$ and incubated for $24 \mathrm{~h}$. Apo-ONE ${ }^{\mathrm{TM}}$ caspase reagent $(100 \mu \mathrm{L} ; 1: 100$ fluorescent substrate and lysis buffer) was added to each well, followed by gentle mixing (360 rpm, $30 \mathrm{~s}$ ) and incubation at $37^{\circ} \mathrm{C}, 1 \mathrm{~h}$. The fluorescence intensity was measured (excitation, $485 \mathrm{~nm}$; emission, $538 \mathrm{~nm}$ ) using a Fluorskan Ascent microplate reader. Background fluorescence was determined from the cell culture medium alone and subtracted from all experimental values. The Caspase 3/7 activity was expressed as folds over control after $60 \mathrm{~min}$ incubation.

\subsection{Statistics}

All data are expressed as means \pm SEM of quadruplicate experiments. One-way analysis of variance (ANOVA; PASW Statistics for Windows 18; SPSS Inc., Chicago, IL, USA) was used to test for differences between red macroalgal species as well as treatment concentrations. Where differences did exist, the source of the differences at a $p \leqslant 0.05$ significance level was identified by the Student-Newman-Keuls multiple range test. Two-way analysis of variance (MANOVA, PASW Statistics) was used to test for interactions between red macroalgal species and treatment concentrations. Student's $t$-test for independent samples was used to test for differences between low- and high-UV C. crispus specimens at a significance level of $p \leqslant 0.05$ where appropriate (PASW Statistics).

Acknowledgments: This research was funded by the following: Natural Sciences and Engineering Research Council of Canada (NSERC) Discovery Grant to YVY; Ryerson University Postdoctoral Fellowship to YA; Ryerson Undergraduate Research Opportunities Scholars Program Award to CK; NSERC Undergraduate Student Research Awards to CK and ST; Ryerson University, Faculty of Community Services Research funds to YVY. The authors thank Michael Leadley of the Mass Spectrometry Facility for Small Molecules at the Hospital for Sick Children (Toronto, ON, Canada) for his technical support.

Author Contributions: YA and YVY conceived and designed the experiments; YA, ST and CK performed the experiments; YA, ST and YVY analyzed the data; YVY wrote the paper with input from YA and ST.

Conflicts of Interest: The authors declare no conflicts of interest.

\section{References}

1. Yuan, Y.V. Marine algal constituents. In Marine Nutraceuticals and Functional Foods; Barrow, C., Shahidi, F., Eds.; CRC Press; Taylor and Francis Group: Boca Raton, FL, USA, 2008; pp. 259-296.

2. Yang, Y.J.; Nam, S.-J.; Kong, G.; Kim, M.K. A case-control study on seaweed consumption and the risk of breast cancer. Br. J. Nutr. 2010, 103, 1345-1353. [CrossRef] [PubMed]

3. Jemal, A.; Bray, F.; Center, M.M.; Ferlay, J.; Ward, E.; Forman, D. Global cancer statistics. CA. Cancer J. Clin. 2011, 61, 69-90. [CrossRef] [PubMed]

4. Jeong, J.; Yang, W.; Ahn, M.; Kim, K.C.; Hyun, J.W.; Kim, S.-H.; Moon, C.; Shin, T. Protective effect of the methanol extract of Polyopes lancifolia (Harvey) kawaguchi et wang against ionizing radiation-induced mouse gastrointestinal injury. Korean J. Vet. Res. 2011, 51, 177-183.

5. Guinea, M.; Franco, V.; Araujo-Bazán, L.; Rodríguez-Martín, I.; González, S. In vivo UVB-photoprotective activity of extracts from commercial marine macroalgae. Food Chem. Toxicol. 2012, 50, 1109-1117. [CrossRef] [PubMed]

6. Ryu, B.-M.; Qian, Z.-J.; Kim, M.-M.; Nam, K.W.; Kim, S.-K. Anti-photoaging activity and inhibition of matrix metalloproteinase (MMP) by marine red alga, Corallina pilulifera methanol extract. Rad. Phys.Chem. 2009, 78, 98-105. [CrossRef] 
7. Kim, E.J.; Park, S.Y.; Hong, J.; Shin, M.; Lim, S.S.; Shin, H.-K.; Park, J.H.Y. Inhibitory effect of the methanolic extract of Symphyocladia latiuscula on the growth of HT-29 human colon cancer cells. J. Korean Soc. Food Sci. Nutr. 2007, 36, 431-438. [CrossRef]

8. Higashi-Okai, K.; Otani, S.; Okai, Y. Potent suppressive effect of a Japanese edible seaweed, Enteromorpha prolifera (Sujiao-nori) on initiation and promotion phases of chemically induced mouse skin tumorigenesis. Can. Lett. 1999, 140, 21-25. [CrossRef]

9. Cho, E.J.; Rhee, S.H.; Park, K.Y. Antimutagenic and cancer cell growth inhibitory effects of seaweeds. J. Food Sci. Nutr. 1997, 2, 348-353.

10. Schmid, D.; Schürch, C.; Zülli, F.; Nissen, H.-P.; Prieur, H. Mycosporine-like amino acids: Natural UV-screening compounds from red algae to protect the skin against photoaging. SÖFW-J. 2003, 129, $38-42$.

11. Schmid, D.; Schürch, C.; Zülli, F. Mycosporine-like amino acids from red algae protect against premature skin-aging. Euro. Cosmet. 2006, 9, 1-4.

12. Ceccoli, J.; Costello, B.; Pillai, S. Marine Extracts and Biofermentations for Use in Cosmetics. U.S. Patent No. 8,202,519 B2, 3 April 2008.

13. Yuan, Y.V.; Westcott, N.D.; Hu, C.; Kitts, D.D. Mycosporine-like amino acid composition of the edible red alga, Palmaria palmata (Dulse) harvested from the west and east coasts of Grand Manan Island, New Brunswick. Food Chem. 2009, 112, 321-328. [CrossRef]

14. Yuan, Y.V.; Carrington, M.F.; Walsh, N.A. Extracts from dulse (Palmaria palmata) are effective antioxidants and inhibitors of cell proliferation in vitro. Food Chem. Toxicol. 2005, 43, 1073-1081. [CrossRef] [PubMed]

15. Lohrmann, N.L.; Logan, B.A.; Johnson, A.S. Seasonal acclimatization of antioxidants and photosynthesis in Chondrus crispus and Mastocarpus stellatus, two co-occurring red algae with differing stress tolerances. Biol. Bull. 2004, 207, 225-232. [CrossRef] [PubMed]

16. Collén, J.; Davison, I.R. Stress tolerance and reactive oxygen metabolism in the intertidal red seaweeds Mastocarpus stellatus and Chondrus crispus. Plant Cell Environ. 1999, 22, 1143-1151. [CrossRef]

17. Aguilera, J.; Bischof, K.; Karsten, U.; Hanelt, D.; Wiencke, C. Seasonal variation in ecophysiological patterns in macroalgae from an Arctic fjord. II. Pigment accumulation and biochemical defence systems against high light stress. Mar. Biol. 2002, 140, 1087-1095.

18. Burritt, D.J.; Larkindale, J.; Hurd, C.L. Antioxidant metabolism in the intertidal red seaweed Stictosiphonia arbuscula following desiccation. Planta 2002, 215, 829-838. [CrossRef] [PubMed]

19. Sinha, R.P.; Singh, S.P.; Häder, D.-P. Database on mycosporines and mycosporine-like amino acids (MAAs) in fungi, cyanobacteria, macroalgae, phytoplankton and animals. J. Photochem. Photobiol. B Biol. 2007, 89, 29-35. [CrossRef] [PubMed]

20. Shick, J.M.; Dunlap, W.C. Mycosporine-like amino acids and related gadusols: biosynthesis, accumulation, and UV-protective functions in aquatic organisms. Ann. Rev.Physiol. 2002, 64, 223-262. [CrossRef] [PubMed]

21. Karsten, U.; Sawall, T.; Hanelt, D.; Bischof, K.; Figueroa, F.L.; Flores-Moya, A.; Wiencke, C. An inventory of UV-absorbing mycosporine-like amino acids in macroalgae from polar to warm-temperate regions. Bot. Mar. 1998, 41, 443-453. [CrossRef]

22. Karsten, U.; Sawall, T.; Wiencke, C. A survey of the distribution of UV-absorbing substances in tropical macroalgae. Phycol. Res. 1998, 46, 271-279. [CrossRef]

23. Nakayama, R.; Tamura, Y.; Kikuzaki, H.; Nakatani, N. Antioxidant effect of the constituents of Susabinori (Porphyra yezoensis). J. Am. Oil Chem. Soc. 1999, 76, 649-653. [CrossRef]

24. Shacklock, P.F.; Craigie, J.S. Winter survival and growth of Chondrus crispus in onshore culture tanks. Can. J. Fish. Aqua. Sci. 1986, 43, 263-268. [CrossRef]

25. Volkmann, M.; Gorbushina, A.A. A broadly applicable method for extraction and characterization of mycosporines and mycosporine-like amino acids of terrestrial, marine and freshwater origin. FEMS Microbiol. Lett. 2006, 255, 286-295. [CrossRef] [PubMed]

26. Huovinen, P.; Gómez, I.; Figueroa, F.L.; Ulloa, N.; Morales, V.; Lovengreen, C. Ultraviolet-absorbing mycosporine-like amino acids in red macroalgae from Chile. Bot. Mar. 2004, 47, 21-29. [CrossRef]

27. Gröniger, A.; Sinha, R.P.; Klisch, M.; Häder, D.-P. Photoprotective compounds in cyanobacteria, phytoplankton and macroalgae-A database. J. Photochem. Photobiol. B Biol. 2000, 58, 115-122. [CrossRef]

28. Mass Spectrometry Facility for Small Molecules. Personal communication, 1 October 2007. 
29. Carreto, J.I.; Carignan, M.O.; Montoya, N.G. A high-resolution reverse-phase liquid chromatography method for the analysis of mycosporine-like amino acids (MAAs) in marine organisms. Mar. Biol. 2005, 146, 237-252. [CrossRef]

30. Bischof, K.; Kräbs, G.; Hanelt, D.; Wiencke, C. Photosynthetic characteristics and mycosporine-like amino acids under UV radiation: a competitive advantage of Mastocarpus stellatus over Chondrus crispus at the Helgoland shoreline? Helgol. Mar. Res. 2000, 54, 47-52. [CrossRef]

31. Kräbs, G.; Wiencke, C. Photosythesis, photosynthetic pigments and mycosporine-like amino acids after exposure of the marine red alga Chondrus crispus (Gigartinales, Rhodophyta) to different light qualities. Phycologia 2005, 44, 95-102. [CrossRef]

32. Acadian Seaplants Ltd. Available online: http://www.acadianseaplants.com/edible-seaweed-nutritionalsupplements-ingredient/edible-sea-vegetables/production-of-hana-tsunomata (accessed on 17 December 2015).

33. Mason, D.S.; Schafer, F.; Shick, J.M.; Dunlap, W.C. Ultraviolet radiation-absorbing mycosporine-like amino acids (MAAs) are acquired from their diet by medaka fish (Oryzias latipes) but not by SKH-1 hairless mice. Comp. Biochem. Physiol. Part A 1998, 120, 587-598. [CrossRef]

34. Dunlap, W.C.; Yamamoto, Y. Small-molecule antioxidants in marine organisms: Antioxidant activity of mycosporine-glycine. Comp. Biochem. Physiol. 1995, 112B, 105-114. [CrossRef]

35. Dunlap, W.C.; Masaki, K.; Yamamoto, Y.; Larsen, R.M.; Karube, I. A novel antioxidant derived from seaweed. In New Developments in Marine Biotechnology; LeGal, Y., Halvorson, H., Eds.; Plenum Press: New York, NY, USA, 1998; pp. 33-35.

36. Moo-Puc, R.; Robledo, D.; Freile-Pelegrín, Y. In vitro cytotoxic and antiproliferative activities of marine macroalgae from Yucatán, Mexico. Cien. Mar. 2009, 35, 345-358.

37. Yamamoto, I.; Maruyama, H.; Takahashi, M.; Komiyama, K. The effect of dietary or intraperitoneally injected seaweed preparations on the growth of sarcoma-180 cells subcutaneously implanted into mice. Can. Lett. 1986, 30, 125-131. [CrossRef]

38. Yamamoto, I.; Maruyama, H. Effect of dietary seaweed preparations on 1,2-dimethylhydrazine-induced intestinal carcinogenesis in rats. Can. Lett. 1985, 26, 241-251. [CrossRef]

39. Schulze-Osthoff, K. Apoptosis, Cytotoxicity and Cell Proliferation, 4th ed.; Rode, H.-J., Ed.; Roche Diagnostics GmbH: Mannheim, Germany, 2008; pp. 2-15.

40. Whitehead, K.; Hedges, J.I. Analysis of mycosporine-like amino acids in plankton by liquid chromatography electrospray ionization mass spectrometry. Mar. Chem. 2002, 80, 27-39. [CrossRef]

Sample Availability: Samples of the extracts and limited availability of purified MAAs are available from the authors.

(C) 2016 by the authors; licensee MDPI, Basel, Switzerland. This article is an open access article distributed under the terms and conditions of the Creative Commons by Attribution (CC-BY) license (http://creativecommons.org/licenses/by/4.0/). 